\title{
Linking Psychological Empowerment to Job Satisfaction and Organizational Commitment: Investigating the Mediating Effect of Organizational Trust
}

\author{
Sanad A. Alajmi ${ }^{1}$ \\ ${ }^{1}$ Department of Development, Public Authority for Industry, Kuwait \\ Correspondence: Sanad A. Alajmi, Department of Development, Public Authority for Industry, Kuwait. E-mail: \\ alajmisanad@hotmail.com
}

Received: May 23, 2016

Accepted: June 1, 2016

Online Published: September 20, 2016

doi:10.5539/ijbm.v11n10p120

URL: http://dx.doi.org/10.5539/ijbm.v11n10p120

\begin{abstract}
The main purpose of this research is to examine the influence of psychological empowerment and organizational trust on job satisfaction and organizational commitment among Kuwait free trade zone employees. Data were obtained for this research through a set of questionnaire which was divided into four parts and administered to a total of 271 respondents. The results showed that psychological empowerment mainly affects employees' job satisfaction and organizational commitment. The results indicated that two dimensions of psychological empowerment, i.e. Meaning and Impact, are significant and positively related to job satisfaction. The existing literature supports the relationships between psychological empowerment dimensions and three dimensions of organizational commitment: normative, continuance, and affective commitment. However, results from this study showed inconsistency. The results showed that only one dimension of Psychological Empowerment, Meaning, is significant and positively Associated to Affective Commitment; two dimensions of Psychological Empowerment, Meaning and Competence, are significant and positively Associated to Normative Commitment; and no dimensions of Psychological Empowerment are statistically contributed to Continuance Commitment. Moreover, analysis has also showed that organizational trust mediates the relationships between psychological empowerment, job satisfaction and organizational commitment. Some practical implications are also discussed. The research concludes with limitations and future research suggestions to enhance psychological empowerment in public and private organizations in Kuwait.
\end{abstract}

Keywords: psychological empowerment, job satisfaction, organizational commitment, organizational trust, Kuwait free trade zone

\section{Introduction}

In light of the global competition and rapid changes in the business environment, organizations seek to enhance the efficiency of human resources through the adoption of managerial applications that achieve optimum utilization of the human resources. One of these applications is empowerment. Employees who feel empowered they are Contribute more in organizational effectiveness (Chen \& Chen, 2008; Liu, Fellows \& Chiu, 2006).

The notion of psychological empowerment has acquired wide acceptance in both theories and management practices (Conger \& Kanungo, 1988; Donovan, 1994; Hall, 2008; Kanter, 1989; Spreitzer, 1995; Thomas \& Velthouse, 1990). There is a large body of research during the past two decades, which looked at the concept of psychological empowerment and the investigation of its causes and consequences. It is generally accepted that this concept consists of four dimensions, i.e. Meaning, Competence, Self-Determination, and Impact (Spreitzer, 1995; Thomas and Velthouse, 1990), and is linked with a number of different work behaviors like employees' performance and attitudes (Fulford \& Enz, 1995 ; Hall, 2008; Koberg, 1999; Spreitzer, 1995, 1996; Suzik, 1998), job satisfaction (Gazzoli et al., 2010; Avey et al., 2008; Bordin et al., 2007; Ugboro \& Obeng, 2000) and organizational commitment (Dehkordi et al., 2011; Joo et al., 2010; Chen \& Chen, 2008; Bhatnagar, 2005).

Empowerment is mainly concerned with the establishment of trust between employees and managers, which motivates them to participate in decision-making. Despite that, only a few researches have studied the relationship between these concepts, especially trust, to mediate the effects of psychological empowerment. Previous studies has concentrated mainly on the effects of empowerment on trust from the point of view of 
managers (Gomez \& Rosen, 2001; Laschinger \& Finegan, 2005; Moye \& Henkin, 2005). Therefore, these two notions should be tested from the perspective of employees to clarify their relationship with each other, and trust, as mediator variable, should be examined. In addition, research on psychological empowerment, organizational commitment, and job satisfaction has been conducted in various organizational settings, but very few studies pertaining to the identification of the level of commitment and job satisfaction of employees working in Kuwait Free Zone have been tackled.

The aim of this paper is to examine the effects of psychological empowerment on job satisfaction and organizational commitment. Also, the role of organizational trust, as mediator variable, will be examined. This paper would support and extend existing psychological empowerment research and attempt to fill the gap in the literature considering the different relations between the perceptions of psychological empowerment, organizational commitment, job satisfaction, and trust.

\section{Psychological Empowerment}

Empowerment concerns mainly in delegation of authority to a person to perform a specific job, so empowerment is the ability of employees who have the flexibility and the freedom to make organizational decisions (Greasley et al., 2008). The concept of empowerment here is in line with traditional management concepts which focus mainly on the lines of hierarchy authority in an organization (Greasley et al., 2005). Consequently, there are several researchers who defined empowerment as a way to improve the decision-making process at the low levels of the organization and enhance staff experience in the workplace (Moye \& Henkin, 2005).

Bowen and Lawler (1992) define empowerment as a tool to help people make the best decision; while Conger and Kanungo (1988) define psychological empowerment as a motivational constructs. Empowerment as a motivational construct means understanding of individuals to their independence and possession of authority. If you enable these individuals, they feel empowered; they feel that they have power and control over their jobs. If they feel this, it is strengthening the power of self-determination, self-worth and self-efficiency (Dehkordi et al., 2011).

Thomas and Velthouse (1990) defined the norm of psychological empowerment as a set of four perceptions that reflects the employee's role in terms of meaning (the value of the work) and efficiency (the ability to perform the work), and freedom of choice (choice in initiating and organizing procedures) and effectiveness (the ability to influence the results regulatory). Moreover, Menon (2001) classified employee empowerment into three main categories: (1) as an act, the act is to give power to the people; (2) as a process, the process that leads to the practice of power; and (3) as a psychological condition, the perception of the individual which can be measured.

There are some internal and external factors, which cause an individual to be more dedicated and self-motivated at work. One of these internal factors is the sense of psychological empowerment as it enhances predictability, understanding of self-esteem, commitment, and job satisfaction. This integrative psychological approach to the concept of employee empowerment has been developed based on the hypothesis that the psychological experience of power is the reason for the employee's sense of empowerment (Jha, 2011). Psychological empowerment is seen as a motivational tool where power and control of internal work act as the stimuli of an individual, which eventually increases conviction about his effectiveness at work (Conger and Kanungo, 1988).

In the literature, there are more than one classification of the components of empowerment. One of the most significant classifications applied in scientific texts is by Spreitzer (1995). He identifies four dimensions of empowerment as follows: meaning, competence or self-efficacy, self-determination, and impact.

Despite having organizational benefits and individual advantages from empowerment, because of competitive environment and the efforts of organizations to achieve efficiency and effectiveness, most of the research nowadays focus on organizational benefits of empowerment that reflect the need for such empowerment. Research shows that organizations that have implemented empowerment have seen significant progress in the economic field (Applebaum et al., 1999).

\subsection{Psychological Empowerment and Job Satisfaction}

Job satisfaction is another important factor in career success as it increases employee efficiency in the organization. Researchers consider that job satisfaction may lead to organizational commitment and productivity. Many researchers have tried to identify the various elements of job satisfaction and study its effects on the productivity of individuals (Hong $\mathrm{Lu}$ et al., 2007). Job satisfaction is a phenomenon that transcends the borders of the organization or company, and its impact on the individual life outside the organization (Robbins, 2002). At the same time, job satisfaction is of great importance for the staff because it requires managers to pay attention to the effects of job satisfaction on the behavior of individuals. Achieving individual's job satisfaction will help 
identify existing problems and difficulties in the organization and determine the cause of the absence of staff.

Seibert et al. (2004) believe that job satisfaction is one of the significant results of psychological empowerment. Research conducted in this area indicates that there is a relationship between empowerment and job satisfaction. Liden et al. (2000) believe that when individuals feel that their performance results effectively in their organization's activities, they are more likely to take part in activities and they are more comfortable in the work assigned to them. Moreover, the research on organizations that adopt Total Quality Management Model (TQM) pointed out that there is a positive relationship between the empowerment of individuals and employee satisfaction as well as customer satisfaction (Ugboro and Obeng 2000). There are also some researchers who found that psychological empowerment positively correlated with job satisfaction or had a positive impact on job satisfaction for employees (Bordin et al., 2007; Gazzoli et al., 2010)

Thomas and Tymon (1994) considered that the three dimensions of psychological empowerment, which are meaning, self-determination, and impact, are factors used to predict job satisfaction for employees. Holdsworth and Cartwright (2003) have conducted a study designed to examine the relationship between the dimensions of psychological empowerment, job stress and job satisfaction for staff of the contact center. Through the study, they found that the three dimensions of psychological empowerment have a positive relationship with job satisfaction for employees. Therefore, they considered these three dimensions as factors to predict job satisfaction. Thomas and Tymon (1994) believe that empowerment is more likely to appear with higher levels of job satisfaction. They also stressed that empowerment enhances the rewards system, and therefore empowerment should be linked positively with job satisfaction. Laschinger et al. (2005), in their study conducted in hospitals, pointed out that when hospital administrators implement empowerment plans, it leads to improved job satisfaction for staff and it increases their motivation. They said that the meaning dimension, which is one of the dimensions of psychological empowerment, is the determining factor for career satisfaction. They also found that there is a positive relationship between the choice, a dimension of empowerment, and job satisfaction as the increase in the freedom of choice granted to employees leads to an improvement in job satisfaction.

There are a number of studies that reach the existence of evidence to support the relationship between the empowerment dimensions and job satisfaction. Carless (2004) concluded that among the four Aspects of empowerment, competence and meaning were more significant in predicting job satisfaction. There appear to be a powerful evidence of a positive relationship between job satisfaction and meaning dimension (Hackman and Oldham, 1980; Spreitzer et al., 1997; Thomas \& Tymon, 1994). In addition, Liden et al. (2000) pointed out that the dimension of the meaning of empowerment has the robust argument for a positive relationship to work satisfaction. Regarding self-determination, the researchers suggested that satisfying a psychological need, will lead to job satisfaction (Conger \& Kanungo, 1988; Greenberger, el at., 1989; Parker, 1993). With regard to the relationship between impact dimension and satisfaction, there is a need for a strong and consistent evidence yet to emerge. On the other hand, Thomas and Tymon (1994) talked about the existence of a positive relationship between impact and job satisfaction. Finally, there is no agreement in the studies on the existence of a relationship between competence dimension and satisfaction. Carless (2004) stated that competence does not significantly affect job satisfaction, while Spreitzer et al. (1997) believe that the competence positively associates with job satisfaction between subordinates, but not between supervisors. Other research also reported that there is no relationship between these variables (Holdsworth \& Cartwright, 2003; Siegall \& Gardner, 2000; Thomas \& Tymon, 1994).

In summary, the published research pointed the existence of a positive relationship between job satisfaction and the two dimensions (meaning and self-determination), but the results are less consistent with the relationship between satisfaction and other dimensions (impact and competence). There is, however, a possibility of interaction between the four dimensions that affect job satisfaction, which can be considered, at least partially, as the reason for the conflicting and contradictory results in some cases regarding the dimensions of impact and competence (Wang \& Lee, 2009). Thus, the first hypothesis is:

H1. There is a significant positive relationship between psychological empowerment and job satisfaction.

\subsection{Psychological Empowerment and Organizational Commitment}

Organizational commitment is considered as one of the leading behavioral changes that is addressed in many of the studies, which focused on the growth of organizational commitment or the consequences of its availability and the relationship of commitment with other important variables such as organizational citizenship, organizational justice, leadership style, climate of communication, and other variables factors.

In an attempt to understand the complex relationship between the employees and the organizations they work for, the researchers focused on the organizational commitment in the workplace. Organizational commitment has 
been defined as a psychological state that links an employee to an organization, thereby reducing the incidence of turnover (Allen \& Meyer, 1990), and as a mindset that takes different forms and links an individual to a course of action that is of relevance to a particular target (Meyer \& Herscovitch, 2001). Whilst Powell and Meyer (2004) believe that organizational commitment is the result of an individual commitment to the organization's goals and policies.

Meyer and Allen (1991) propose a three-dimensional model of organizational commitment comprised of affective commitment, normative commitment, and continuance commitment. The employees who were empowered will see themselves as more capable to impact their work and their organizations more clearly. It is also expected to implement efforts more than what is required of them, and act independently for them to have a deeper commitment to their organization (Spreitzer, 1995). Employees who feel more empowered are more likely to gain focus by being more committed to their organizations (Eisenberger et al., 1990; Kraimer et al., 1999).

Thomas and Velthouse (1990) suggested that employees who have been empowered have higher levels of focus, initiative, and flexibility, which in turn improve the level of organizational commitment. In other words, when the staff feel that their work has meaning, they have higher levels of commitment to their organization and energy to perform the work.

Many studies investigating the relationship between psychological empowerment and organizational commitment can be found in the literature (e.g. Dehkordi et al., 2011; Joo et al., 2010; Chen \& Chen, 2008; Bhatnagar, 2005). Research has proved the empirical relationship between these two variables with different group of respondents. The researchers argued that the changing nature of labor relations has increased the importance of understanding the nature of the organization commitment (Hislop, 2003). It is also generally assumed that the level of commitment is a key determinant of the results at the organizational level, such as organizational citizenship behavior (Colyle-Shapiro \& Kessler, 2000), as well as the performance (De Cotiis \& Summers, 1987), and control of absenteeism from work (Meyer \& Allen, 1997). Most researchers believe that organizational commitment characterize the psychological state that describes an employee's relationship with his organization and that it has implications for their decision to stay with the organization (Allen \& Grisaffe, 2001). According to Laschinger et al. (2004), psychological empowerment represents a response of employees to structural empowerment conditions. On the other hand, psychological empowerment reflects the ebb and flow of beliefs and orientations of individual people about their work environment and its impact on them (internal and external environment). Thus, greater psychological empowerment leads to an increase in the organizational commitment (Robbinson et al., 1994). Accordingly, the second hypothesis is:

H2. There is a significant positive relationship between psychological empowerment and organizational commitment.

\subsection{Trust and Psychological Empowerment}

Trust is key element in the positive human relations since its existence provides a cooperative environment and gives people a sense of security and connection (Mishra and Morrissey, 1990). Trust is vital in the integration of management practices, such as empowerment, employee performance, efficiency and capability, and organizational commitment. Thus, high trust between employees and supervisors relations mainly constitutes mediator towards management practices, such as empowerment (Ertürk, 2012).

Many researchers tried to find a definition for trust as a concept (Lewicki et al., 2006). Mayer et al. (2005) believe trust is "The willingness of a party to be vulnerable to the actions of another party based on the expectation that the other party will perform a particular action important to the trustor, irrespective of the ability to monitor or control that other party". On the other hand, Rousseau et al. (1998) identified trust, as "a psychological state comprising the intention to accept vulnerability based upon positive expectations of the intentions or behaviors of another". Based on the concepts of trust, most researchers agree on three dimensions of trust, which received considerable acceptance. These are trust in supervisors, trust in colleagues, and trust in organization. For the objectives of this study, it will be focused only on two dimensions, which are trust in supervisors and trust in organization.

\subsection{Trust in Supervisors}

Trust in the supervisor would improve the employee's willingness to accept greater responsibilities through empowerment. When employees believe that they cannot trust their supervisor, it will limit the employee's desire to contribute to the organization. The successful results of psychological empowerment require raising the level of trust between the employee and the supervisor, as well as between staff and top management. When 
subordinate trusts the supervisor, that leads to improved performance of the work and contribute to the improvement of organizational citizenship behavior, and encourages subordinate to maintain the relationship and stay with the organization (Colquitt et al., 2007; Brower et al., 2009); and the employee creates value for the organization through the extra efforts of subordinates (Mayer \& Gavin, 2005).

Tan and Tan (2000) confirmed that there is a positive relationship between trust in the supervisor and factors of ability, integrity and charity. Moreover, when there is an environment based on trust, it can lead to a sense of responsibility among the subordinates (Cropanzano \& Mitchell, 2005) and improvement on their commitment (Brower et al., 2009). In addition, individuals who receive support from their direct supervisor will have greater sense of self-efficiency, which in turn supports a sense of their ability to influence and be independent (Spreitzer, 1996).

Also, the presence of this kind of trust increases the subordinates' expectation of better future, which serves as an extra motivation for them and makes them do their best (Dirks \& Ferrin, 2002). Chan et al. (2008) confirm that the effectiveness of the use of psychological empowerment to influence the behavior of workers depends on the level of subordinates' trust in their supervisors.

\subsection{Trust in the Organization}

Trust in the organization plays a significant role in the organizational stability and well-being of the employee (Cook and Wall, 1980). Organizational trust can be expected to link to other factors important for the effective functioning of organizations in today's competitive business environment (Brashear et al., 2003; Parnell \& Crandall 2003). Organizations that treat employees unfairly and do not appreciate their contributions could lead to reduced employee trust and commitment, job satisfaction, resulting in increased job turnover (Driscoll, 1978; Tan, 2000).

To create organizational trust, it is important that organizations make employees feel supported and provide them with rewards, such as increased income and independence at work (Tan, 2000; Kim et al., 2004). In addition, the creation of an environment of trust is a function of the organizations because they also improve organizational effectiveness and the individual's willingness to stay (Whitener et al., 1998; Gilbert \& Tang, 1998). Covey (1998) believes that the only way to take advantage of empowerment is through the promotion of trust in the organization's culture. In addition, psychological empowerment is linked to organizational effectiveness when employees work in an environment of trust. Moreover, Andrews (1994) demands that shortage of trust within the organization may lead to failure, where the formation of subtle and invisible barriers prevents efforts to enable employees to achieve success.

There are number of studies that have discussed the relationship of trust to empowerment. One such study, Gomez and Rosen (2001), proved the existence of a positive relationship between trust level for supervisors and subordinates and the policies empowering subordinates, as the ability of trust that leads to improve the relationship and thus increasing the supervisor's attitudes towards the empowerment of their subordinates. Also, a study of Jian et al. (2009) showed that the relationship between supervisors and subordinates affect their performance levels as the availability of trust leads to improve the relationship and thus increasing the supervisors attitudes towards the empowerment of their subordinates.

In addition, former research emphasized mainly on the effects of empowerment on trust and the relationship between them from the point of view of managers (Gomez \& Rosen, 2001; Laschinger \& Finegan, 2005; Moye $\&$ Henkin, 2005). Therefore, these two concepts should be tested from the perspective of subordinates. It is also important to know the nature of empowerment and how it works and its relationship to the trust in the success of empowerment efforts. In order to promote the positive results of psychological empowerment, employees must be confident that the organization really wants to empower them, and be prepared to recognize and exploit the empowerment opportunities that is given to them (Ertürk, 2010).

Consequently, the researcher expects that the relationship between psychological empowerment and job satisfaction and organizational commitment will be stronger for employees who have more trust in their supervisors and organizations. Thus, the existence of a higher level of trust in the employees toward their supervisors and organizations would strengthen the impact of psychological empowerment on job satisfaction and organizational commitment. The third hypothesis of the study can be formulated as follows:

H3. "The level of trust-as a mediator variable-significantly affects the relationship between psychological empowerment on one hand and job satisfaction and organizational commitment on the other hand."

This main hypothesis divided into sub-hypothesis are as follows:

H3.a. "Subordinate trust in direct supervisor-as a mediator variable-significantly affects the relationship between 
psychological empowerment on one hand and job satisfaction and organizational commitment on the other hand."

H3.b. "Subordinate trust in organization-as a mediator variable-significantly affects the relationship between psychological empowerment on one hand and job satisfaction and organizational commitment on the other hand."

\section{Methods}

\subsection{Sample and Procedure}

In order to test the proposed hypotheses empirically, a simple random sampling was used to collect data from Kuwait trade free zone. Data was obtained through a questionnaire. 300 Questionnaires were sent. Of the 300 questionnaires sent, 210 completed the questionnaires and returned it with a response rate of $70 \%$. Some demographic data was collected, such as gender, age, level of educational and experience at work. The sample was $57.1 \%$ male and the average respondent was 36 years old (standard deviation of 7.3 years) with ages ranging from 23 to 53 years old. Educational level of respondents shows that $47.1 \%$ of them have a university degree, and had worked for their companies for an average of 13 years (standard deviation of 7.6 years) with a range of 1 year to 30 years.

\subsection{Measures}

All items were measured on a 5-point Likert-type scale where 1 indicates "strongly disagree" and 5 indicates "strongly agree". In this study, Psychological empowerment was measured with (12) items and (4) dimensions namely meaning, competence, self-determination, and impact (Spreitzer, 1995). Organizational Commitment scale included (18) items and (3) dimensions namely Affective Commitment, Continuance Commitment, and Normative Commitment (Meyer \& Allen, 1997). Organizational trust was measured with a questionnaire adapted from Nyhan and Marlowe's (1997). This questionnaire has eight items which measure employees' trust in the immediate supervisor and 4 items which measure employees' attitudes towards their internal organization. Finally, Job Satisfactions was measured with a questionnaire adapted from Fernand and Awamleh (2006). This questionnaire has seven items to assess the level of job satisfaction among employees. It is worth to mention here that a conversion for the negative statements were created using SPSS V.23.

\section{Results}

\subsection{General Information}

Table 1 below represents the profile of the sample members who participated in the study.

Table 1. Profile of the sample members who participated in the study

\begin{tabular}{|c|c|c|c|}
\hline Variable & Category & Frequency & Percent \\
\hline \multirow{3}{*}{ Gender } & Male & 120 & $57.1 \%$ \\
\hline & Female & 90 & $42.9 \%$ \\
\hline & Total & 210 & $100 \%$ \\
\hline \multirow{8}{*}{ Age } & Category & Frequency & Percent \\
\hline & Less than 24 Years & 12 & $5.7 \%$ \\
\hline & 25 to 30 Years & 60 & $28.6 \%$ \\
\hline & 31 to 35 Years & 30 & $14.3 \%$ \\
\hline & 36 to 40 Years & 39 & $18.6 \%$ \\
\hline & 41 to 45 Years & 51 & $24.3 \%$ \\
\hline & Older than 46 & 18 & $8.6 \%$ \\
\hline & Total & 210 & $100 \%$ \\
\hline \multirow{6}{*}{ Educational Level } & Category & Frequency & Percent \\
\hline & High school or less & 36 & $17.1 \%$ \\
\hline & Diploma degree & 72 & $34.3 \%$ \\
\hline & University degree & 99 & $47.1 \%$ \\
\hline & Higher degree & 3 & $1.4 \%$ \\
\hline & Total & 210 & $100 \%$ \\
\hline Experience at Work & Category & Frequency & Percent \\
\hline
\end{tabular}




\begin{tabular}{lll}
\hline Less than 5 years & 36 & $17.1 \%$ \\
5 to 10 years & 63 & $30.0 \%$ \\
11 to 15 years & 33 & $15.7 \%$ \\
16 to 20 years & 33 & $15.7 \%$ \\
21 to 25 years & 33 & $15.7 \%$ \\
More than 25 years & 12 & $5.7 \%$ \\
Total & $\mathbf{2 1 0}$ & $\mathbf{1 0 0 \%}$ \\
\hline
\end{tabular}

\subsection{Reliability Analysis}

Table 2 below illustrates the reliability indices of the dimensions of Psychological Empowerment, Organizational Commitment, Trust, and Job Satisfaction.

Table 2. Reliability indices of factors of psychological empowerment, organizational commitment, trust, and job satisfaction

\begin{tabular}{lll}
\hline Scale & Number of Items & Cronbach's Alpha \\
\hline Meaning & 3 & 0.81 \\
Competence & 3 & 0.92 \\
Self-Determination & 3 & 0.73 \\
Impact & 3 & 0.87 \\
Psychological Empowerment (overall) & 12 & 0.86 \\
Affective Commitment & 6 & 0.80 \\
Continuance Commitment & 6 & 0.77 \\
Normative Commitment & 6 & 0.81 \\
Organizational Commitment (overall) & 18 & 0.87 \\
Trust in Supervisors & 8 & 0.95 \\
Internal Organizational trust & 4 & 0.91 \\
Organizational Trust (overall) & 12 & 0.94 \\
Job Satisfaction (overall) & 7 & 0.74 \\
Valid $\boldsymbol{n}$ & 70 & \\
\hline
\end{tabular}

Cronbach's alpha coefficients for the dimensions of Psychological Empowerment consisted of a range of ( 0.73 to 0.92), for the dimensions of Organizational Commitment consisted of a range of (0.77 to 0.81$)$, while these coefficients for the dimensions of Organizational Trust consisted of a range of (0.91 to 0.95 ), and finally for the Job Satisfaction the Cronbach's alpha coefficient was 0.74. It is clear that the Cronbach's alpha scale reliability values for the variables constructed in the model consisted of a range of 0.71 to 0.94 , which was beyond the minimum acceptable level of 0.70 (George \& Mallery, 2003).

\subsection{Descriptive Statistics among the Variables}

Table 3 below represents means, standard deviations, and percentages among the variables. 
Table 3. Descriptive statistics among the variables

\begin{tabular}{lllll}
\hline & $\begin{array}{l}\text { Variables } \\
\text { Psychological } \\
\text { Empowerment }\end{array}$ & $\begin{array}{l}\text { Organizational } \\
\text { Commitment }\end{array}$ & The Level of Trust & Job Satisfaction \\
\hline Means & 3.7 & 3.4 & 3.8 & 3.6 \\
St.Dev. & 1.1 & 1.2 & 1.1 & 1.1 \\
HD & $5.4 \%$ & $8.1 \%$ & $5.0 \%$ & $6.7 \%$ \\
D & $15.5 \%$ & $18.6 \%$ & $11.9 \%$ & $13.7 \%$ \\
IK & $13.6 \%$ & $18.4 \%$ & $16.9 \%$ & $14.1 \%$ \\
A & $36.7 \%$ & $36.0 \%$ & $32.4 \%$ & $44.5 \%$ \\
HA & $28.8 \%$ & $18.9 \%$ & $33.8 \%$ & $21.0 \%$ \\
Total & $\mathbf{1 0 0} \%$ & $\mathbf{1 0 0} \%$ & $\mathbf{1 0 0 \%}$ & $\mathbf{1 0 0 \%}$ \\
\hline
\end{tabular}

$\mathrm{HD}=$ Highly Disagree, $\mathrm{D}=$ Disagree, $\mathrm{IK}=\mathrm{I}$ don't know, $\mathrm{A}=$ Agree, HA= Highly Agree.

\section{Correlations Tests}

5.1 Correlations between the Variables under the Study

The following Table 4 represents the correlation matrix of the main variables.

Table 4. Correlation matrix of the IV, DVs and the mediator

\begin{tabular}{lllll}
\hline Variables & $\mathbf{1}$ & $\mathbf{2}$ & $\mathbf{3}$ & $\mathbf{4}$ \\
\hline Psychological Empowerment & 1 & & & \\
Job Satisfaction & $0.587^{* *}$ & 1 & & \\
Organizational Commitment & $0.474^{* *}$ & $0.517^{* *}$ & 1 & \\
Organizational Trust & $0.528^{* *}$ & $0.634^{* *}$ & $0.579^{* *}$ & 1 \\
\hline
\end{tabular}

**. Correlation is significant at the 0.01 level (2-tailed).

Table 4 revealed a highly significant correlation of 0.597 and 0.474 (p-value $<0.01$ ) between Psychological Empowerment as IV and Job Satisfaction and Organizational Commitment as DVs. Moreover, Psychological Empowerment has a highly significant correlation of 0.528 ( $p$-value $<0.01$ ) with the Mediator variable (i.e. Trust). The next path of the model (i.e. Mediator and DVs) consists of a highly significant correlation of 0.634 and 0.579 (sig. $<0.01$ ) respectively.

\subsection{Correlations between the Dimensions}

The following Table 5 represents the correlation matrix of the dimensions.

Table 5. Correlation matrix of the dimensions of the variables

\begin{tabular}{|c|c|c|c|c|c|c|c|c|c|}
\hline & 1 & 2 & 3 & 4 & 5 & 6 & 7 & 8 & 9 \\
\hline ME & 1 & & & & & & & & \\
\hline $\mathrm{CO}$ & $0.579 * *$ & 1 & & & & & & & \\
\hline SED & $0.409 * *$ & $0.478^{* *}$ & 1 & & & & & & \\
\hline I & $0.308^{* *}$ & 0.103 & $0.385^{* *}$ & 1 & & & & & \\
\hline JS & $0.526^{* *}$ & $0.320^{* *}$ & $0.424 * *$ & $0.434^{* *}$ & 1 & & & & \\
\hline $\mathrm{AC}$ & $0.545^{* *}$ & $0.340 * *$ & $0.275^{*}$ & $0.311 * *$ & $0.539 * *$ & 1 & & & \\
\hline $\mathrm{CC}$ & $0.243 *$ & 0.224 & 0.109 & -0.093 & 0.219 & $0.282^{*}$ & 1 & & \\
\hline $\mathrm{NC}$ & $0.500^{* *}$ & $0.448 * *$ & 0.227 & 0.210 & $0.490 * *$ & $0.690^{* *}$ & $0.439^{* *}$ & 1 & \\
\hline TS & $0.407 * *$ & $0.508^{* *}$ & $0.395^{* *}$ & 0.229 & $0.600 * *$ & $0.378^{* *}$ & $0.298^{*}$ & $0.486^{* *}$ & 1 \\
\hline IT & $0.405 * *$ & $0.394 * *$ & $0.295^{*}$ & 0.078 & $0.530 * *$ & $0.458 * *$ & $0.327 * *$ & $0.651 * *$ & $0.611 * *$ \\
\hline
\end{tabular}

**. Correlation is significant at the 0.01 level (2-tailed).

*. Correlation is significant at the 0.05 level (2-tailed).

$\mathrm{ME}=$ Meaning, $\mathrm{CO}=$ Competence, $\mathrm{SED}=$ Self-Determination, $\mathrm{I}=$ Impact, JS $=$ Job Satisfaction, $\mathrm{AC}=$ Affective Commitment, $\mathrm{CC}=$ Continuance Commitment, $\mathrm{NC}=$ Normative Commitment, $\mathrm{TS}=$ Trust in supervisors, $\mathrm{IT}=$ Internal Organizational Trust. 
The data were analyzed using an intercorrelation matrix to show the correlations between the dimensions of the dependent variable and each dimension of independent variables as well as the correlations between the dimensions of independent variables. The correlation matrix shows that there are significant positive correlations under significance level set at the $5 \%$ between three dimensions of the IV namely Meaning, Competence, Self-determinations and the dimensions of the mediate variable (MV) (p-value $<0.01$ ), while the fourth dimension of Psychological Empowerment (i.e. Impact) is not correlated with the dimensions of the MV (p-value > 0.05). The two dimensions of the MV (i.e. Trust) were correlated positively with DVs (Job Satisfaction and Organizational Commitment) since p-value $<0.01$ (high significance), as shown in the above table.

\section{Testing Hypothesis}

We will use the data illustrated in Table 5 to discuss hypotheses 1 and 2 of the study.

H01: There is a significant positive relationship between Psychological Empowerment and job satisfaction.

H02: There is a significant positive relationship between Psychological Empowerment and Organizational Commitment.

Table 6. Regression analysis for testing $\mathrm{H} 1$ and $\mathrm{H} 2$

\begin{tabular}{|c|c|c|c|c|c|c|}
\hline IV & DV & $\mathrm{R}^{2}$ & Adjusted $\mathrm{R}^{2}$ & $\mathrm{~F}$ & $\begin{array}{l}\text { Unstandardized } \\
\text { Coefficients }\end{array}$ & $\beta$ \\
\hline $\begin{array}{l}\text { Model 1: } \\
\text { PE }\end{array}$ & JS & 0.345 & 0.335 & $35.8^{* *}$ & $\begin{array}{ll}\mathrm{a} & 10.08(2.6) \\
\mathrm{b} & 0.341(0.06)\end{array}$ & $0.587 * *$ \\
\hline $\begin{array}{l}\text { Model 2: } \\
\text { PE }\end{array}$ & $\mathrm{OC}$ & 0.224 & 0.213 & $19.7 * *$ & $\begin{array}{ll}\mathrm{a} & 30.63(7.0) \\
\mathrm{b} & 0.69(0.155)\end{array}$ & $0.474 * *$ \\
\hline
\end{tabular}

** The direct effect (Beta) is significant at the 0.01 level (2-tailed).

$\mathrm{IV}=$ Independent Variable, DV= Dependent Variable, PE $=$ Psychological Empowerment, JS= Job Satisfaction, OC $=$ Organizational Commitment, $\mathrm{a}=$ Constant (unstandardized), $\mathrm{b}=$ slope (unstandardized).

Figure between the bracts refers to Standard Error of the coefficient:

In Model 1, "Psychological Empowerment" explains about 33.5\% of the variation in the dependent variable," Job Satisfaction". From the coefficient value, it also suggests that these two variables were highly positively correlated. In Model 2, "Psychological Empowerment" explains about 21.3\% of the variation in the dependent variable," Organizational Commitment". A brief look at the F ratios (35.8, and 19.7) reveals that the significant value is less than 0.01 , thus, the regression model is significant, as shown in Table 5. It is clear from the above table that Psychological Empowerment is significantly and positively related to Job Satisfaction $\left(\beta=0.587^{* *}\right)$ and Organizational Commitment $\left(\beta=0.474^{* *}\right)$. From this discussion, both of $\mathrm{H} 01$ and $\mathrm{H} 02$ are supported by the data.

Using simple regression model and the results of Table 6, Job Satisfaction and Organizational Commitment could be predicted with the following linear equations respectively:

Eq. (1):Organizational Commitment $=10.08+0.341$ (Job Satisfaction).

Eq. (2): Organizational Commitment $=30.63+0.69$ (Organizational Commitment).

To investigate the relationships between dimensions of Psychological Empowerment and Job Satisfaction, the data illustrated in Tables 7 and 8 will be used.

Table 7. Model summary

\begin{tabular}{lllll}
\hline $\mathbf{R}$ & R Square & Adjusted R Square & F & p-value \\
\hline $0.617^{\mathrm{a}}$ & 0.381 & 0.343 & $10.0^{\mathrm{b}}$ & 0.0000 \\
\hline
\end{tabular}

a. Dependent Variable: Job Satisfaction.

b. Predictors: (Constant), Impact, Competence, Self Determination, Meaning.

In Table 7, the four dimensions of Psychological Empowerment namely Meaning, Competence, Self-Determination, and Impact explains about $34.3 \%$ of the variation in the dependent variable," Job Satisfaction". From the coefficient value, it also suggests that these five variables were highly positively 
correlated (Multiple R correlation coefficient is 0.617 ). As shown in Table 8, the $\mathrm{F}$ ratio is highly significant ( $p$-value $<0.01$ ), and the regression model is significant.

Table 8. Coefficients ${ }^{\mathrm{a}}$ in the model

\begin{tabular}{|c|c|c|c|c|}
\hline \multirow{2}{*}{ Predictors } & \multicolumn{2}{|c|}{ Unstandardized Coefficients } & \multirow{2}{*}{$\begin{array}{l}\text { Standardized } \\
\text { Coefficients } \\
\text { Beta }\end{array}$} & \multirow{2}{*}{ p-value } \\
\hline & $\mathrm{B}$ & Std. Error & & \\
\hline (Constant) & 11.224 & 2.649 & & 0.000 \\
\hline Meaning & 0.632 & 0.207 & 0.384 & 0.003 \\
\hline Competence & -0.021 & 0.229 & -0.012 & 0.926 \\
\hline Self Determination & 0.310 & 0.212 & 0.177 & 0.148 \\
\hline Impact & 0.403 & 0.178 & 0.249 & 0.027 \\
\hline
\end{tabular}

a. Dependent Variable: Job Satisfaction.

Two dimensions of Psychological Empowerment namely Meaning, and Impact are significant and positively related to Job Satisfaction $\left(\beta_{\text {Meaning }}=0.384^{* *}, \beta_{\text {Impact }}=0.249^{* *}\right)$. The other two dimensions of Psychological Empowerment (Competence and Self-Determination) are statistically not contributed to Psychological Empowerment, since their effects are not significant ( $p$-value $>0.10$ ).

To further investigate the relationships between dimensions of Psychological Empowerment and dimensions of Organizational Commitment, the data illustrated in Tables 9 and 10, with help of multiple regression with three steps, will be used.

Table 9. Model summary

\begin{tabular}{llllll}
\hline Model & R & R Square & Adjusted R Square & F $^{\text {d }}$ & p-value \\
\hline 1 & $0.567^{\mathrm{a}}$ & 0.322 & 0.280 & 7.72 & 0.000 \\
2 & $0.314^{\mathrm{b}}$ & 0.099 & 0.043 & 1.78 & 0.143 \\
3 & $0.547^{\mathrm{c}}$ & 0.299 & 0.256 & 6.92 & 0.0000 \\
\hline
\end{tabular}

a. Dependent Variable: Affective Commitment.

b. Dependent Variable: Continuance Commitment.

c. Dependent Variable: Normative Commitment.

d. Predictors: (Constant), Impact, Competence, Self Determination, Meaning.

In Model 1, the four dimensions of Psychological Empowerment namely Meaning, Competence, Self-Determination, and Impact explains about $28.0 \%$ of the variation in the dependent variable," Affective Commitment". From the coefficient value, it also suggests that these five variables were highly positively correlated (Multiple $\mathrm{R}$ correlation coefficient is 0.567 ). As shown in Table 9 , the $\mathrm{F}$ ratio is highly significant $(\mathrm{F}=$ 7.72 , p-value $<0.01$ ), thus, the regression Model 1 is significant. In Model 2, the F ratio is insignificant (p-value $>$ 0.10 ), and only $4.3 \%$ of the variation in the dependent variable "Continuance Commitment" was explained by the four dimensions of Psychological Empowerment. In Model 3, the four dimensions of Psychological Empowerment explain about $25.6 \%$ of the variation in the dependent variable," Normative Commitment". From the coefficient value, it also suggests that these five variables were highly positively correlated (Multiple R correlation coefficient is 0.547 ). As shown in Table 9, the $\mathrm{F}$ ratio is highly significant $(\mathrm{F}=6.92$, $\mathrm{p}$-value $<0.01$ ), thus, the regression Model 3 is significant. 
Table 10. Coefficients in the models

\begin{tabular}{|c|c|c|c|c|}
\hline \multirow{2}{*}{ Predictors } & \multicolumn{2}{|c|}{ Unstandardized Coefficients } & \multirow{2}{*}{$\begin{array}{l}\text { Standardized } \\
\text { Coefficients } \\
\text { Beta }\end{array}$} & \multirow{2}{*}{ p-value } \\
\hline & $\mathrm{B}$ & Std. Error & & \\
\hline \multicolumn{5}{|l|}{ Model $1^{\text {a: }}$ : } \\
\hline (Constant) & 8.108 & 2.827 & & 0.006 \\
\hline Meaning & 0.779 & 0.221 & 0.464 & 0.001 \\
\hline Competence & 0.103 & 0.244 & 0.057 & 0.676 \\
\hline Self Determination & -0.010 & 0.226 & -0.006 & 0.963 \\
\hline Impact & 0.272 & 0.190 & 0.165 & 0.157 \\
\hline \multicolumn{5}{|l|}{ Model $2^{\text {b: }}$} \\
\hline (Constant) & 15.895 & 3.310 & & 0.000 \\
\hline Meaning & 0.394 & 0.259 & 0.232 & 0.133 \\
\hline Competence & 0.162 & 0.286 & 0.088 & 0.574 \\
\hline Self Determination & 0.083 & 0.265 & 0.046 & 0.755 \\
\hline Impact & -0.320 & 0.222 & -0.191 & 0.155 \\
\hline \multicolumn{5}{|l|}{ Model $3^{\mathrm{c}}$ : } \\
\hline (Constant) & 6.638 & 2.966 & & 0.029 \\
\hline Meaning & 0.585 & 0.232 & 0.338 & 0.014 \\
\hline Competence & 0.526 & 0.256 & 0.283 & 0.044 \\
\hline Self Determination & -0.165 & 0.237 & -0.089 & 0.490 \\
\hline Impact & 0.190 & 0.199 & 0.112 & 0.344 \\
\hline
\end{tabular}

a. Dependent Variable: Affective Commitment.

b. Dependent Variable: Continuance Commitment.

c. Dependent Variable: Normative Commitment.

In Model 1, only one dimension of Psychological Empowerment, Meaning, is significant and positively related to Affective Commitment $\left(\beta_{\text {Meaning }}=0.464^{* *}\right)$, while the other three dimensions of Psychological Empowerment (Competence, Self-Determination, and Impact) are statistically not contributed to Affective Commitment since their effects are not significant ( $\mathrm{p}$-value $>0.10$ ). In Model 2, all the dimensions of Psychological Empowerment are statistically not contributed to Continuance Commitment since their effects $(\beta$ 's) are not significant ( $p$-value $>$ 0.10). In Model 3, the first two dimensions of Psychological Empowerment namely Meaning and Competence are significant and positively related to Normative Commitment $\left(\beta_{\text {Meaning }}=0.338^{* *}, \beta_{\text {Competence }}=0.283^{* *}\right)$, while the other two dimensions of Psychological Empowerment (Self Determination, and Impact) are statistically not contributed to Normative Commitment; since their effects are not significant ( $\mathrm{p}$-value >0.10).

H03. "The level of Organizational Trust-as a mediator variable-significantly affects the relationship between Psychological Empowerment on one hand and Job Satisfaction and Organizational Commitment on the other hand."

To gain a better understanding of the role of level of Organizational Trust in this model, its potential mediating effect on the linkage between Psychological Empowerment on one hand and Job Satisfaction and Organizational Commitment on the other hand is shown in Figure 1. This can be accomplished by following the Preacher and Hayes (2008) procedure. This procedure involves the use of bootstrapping in a 2-step procedure. (i) The significance of direct effect is first checked using bootstrapping without the presence of the mediator level of Organizational Trust in the model; and (ii) the significance of indirect effect and associated T-Values are then checked using the path coefficients when the mediator level of Organizational Trust included in the model. 
Table 11. Regression analysis for testing H03

\begin{tabular}{|c|c|c|c|c|c|c|}
\hline Outcome Variable & Predictor(s) & $\mathbf{R}$ & $\mathbf{R}^{2}$ & $\mathbf{F}$ & $\beta$ 's & p-value \\
\hline Organizational Trust & $\begin{array}{l}\text { Psychological } \\
\text { Empowerment }\end{array}$ & 0.53 & 0.28 & $26.2 * *$ & 0.53 & 0.000 \\
\hline Job Satisfaction & $\begin{array}{l}\text { Organizational Trust } \\
\text { Psychological } \\
\text { Empowerment }\end{array}$ & 0.70 & 0.49 & $32.2 * *$ & $\begin{array}{l}0.45 \\
0.35\end{array}$ & $\begin{array}{l}0.000 \\
0.001\end{array}$ \\
\hline Organizational Commitment & $\begin{array}{l}\text { Organizational Trust } \\
\text { Psychological } \\
\text { Empowerment }\end{array}$ & 0.61 & 0.38 & $20.1 * *$ & $\begin{array}{l}0.46 \\
0.23\end{array}$ & $\begin{array}{l}0.000 \\
0.044\end{array}$ \\
\hline
\end{tabular}

** Significant at 0.001 .

It is clear from the table above that Psychological Empowerment is significantly and positively related to Job Satisfaction through the mediator variable (Organizational Trust) since $(\beta=0.45, p-$ value $<0.001)$. In addition, Psychological Empowerment is significantly and positively related to Organizational Commitment through the mediator variable (Organizational Trust) since $(\beta=0.46, p-$ value $<0.05)$. From this discussion, H03 is highly supported by the data.

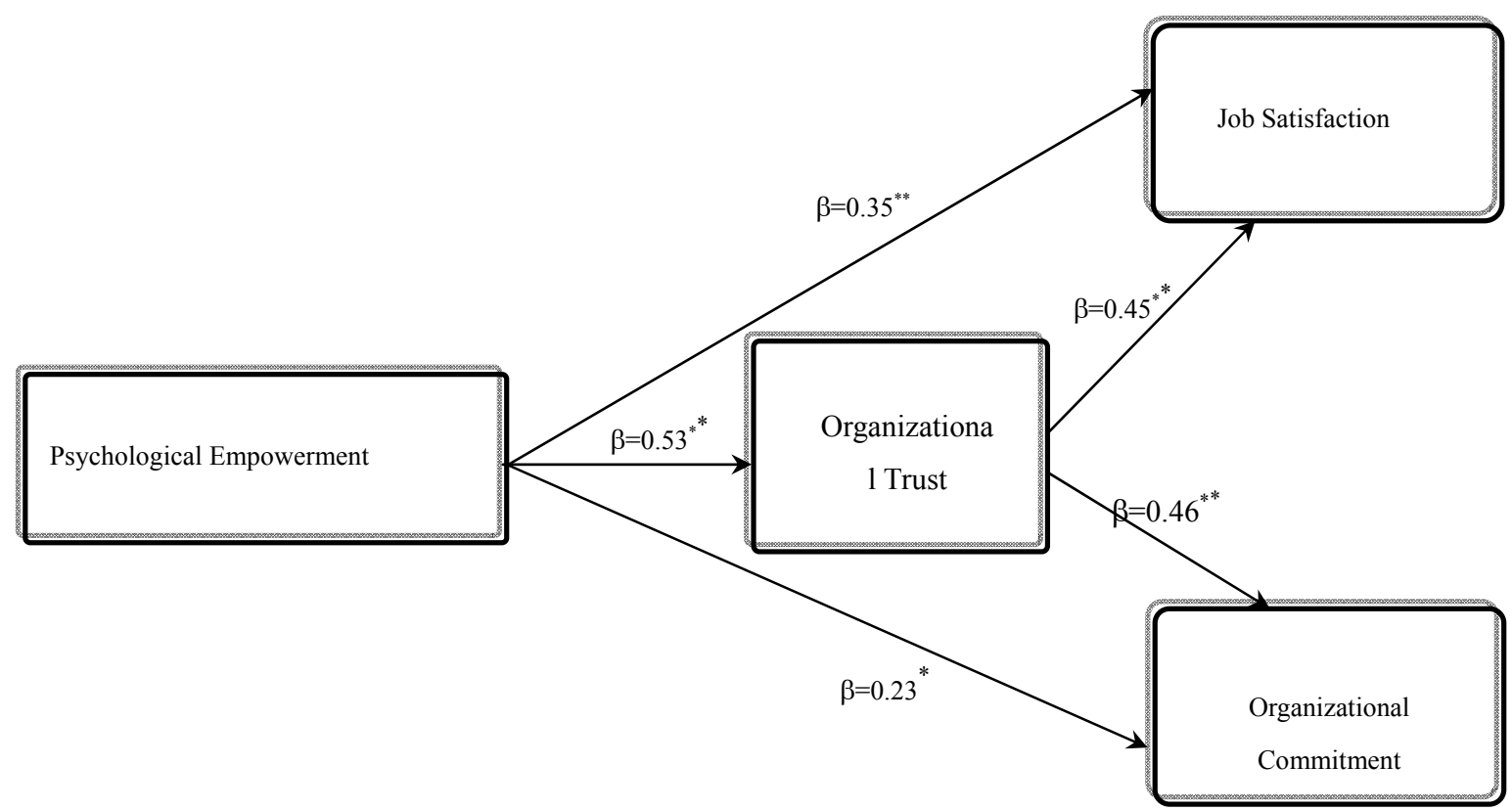

Figure 1. Framework

H3.a. "Subordinate Trust in direct supervisor-as a mediator variable-significantly affects the relationship between Psychological Empowerment on one hand and Job Satisfaction and Organizational Commitment on the other hand."

The data illustrated in Table 12 will be used to discuss the hypothesis H03.a. 
Table 12. Regression analysis for testing H03.a

\begin{tabular}{lllllll}
\hline Outcome Variable & Predictor(s) & $\mathbf{R}$ & $\mathbf{R}^{2}$ & $\mathbf{F}$ & $\beta$ 's & p-value \\
\hline Trust in Supervisors & Psychological Empowerment & 0.52 & 0.27 & $25.7^{* *}$ & 0.52 & 0.000 \\
Job & Trust in Supervisors & & & & 0.40 & 0.000 \\
Satisfaction & Psychological Empowerment & 0.68 & 0.46 & $28.8^{* *}$ & 0.38 & 0.001 \\
Organizational & Trust in Supervisors & & & & 0.32 & 0.009 \\
Commitment & Psychological Empowerment & 0.55 & 0.30 & \multirow{2}{*}{$14.3^{* *}$} & 0.31 & 0.013 \\
\hline
\end{tabular}

** Significant at 0.001 .

It is clear from the table above that the Psychological Empowerment is significantly and positively related to Job Satisfaction through the mediator variable (Subordinate Trust in direct supervisor) since $(\beta=0.40, p-$ value $<$ 0.001). In addition, Psychological Empowerment is significantly and positively related to Organizational Commitment through the mediator variable (Subordinate Trust in direct supervisor) since $(\beta=0.32, p-$ value $<$ 0.01). From this discussion, H03.a is highly supported by the data.

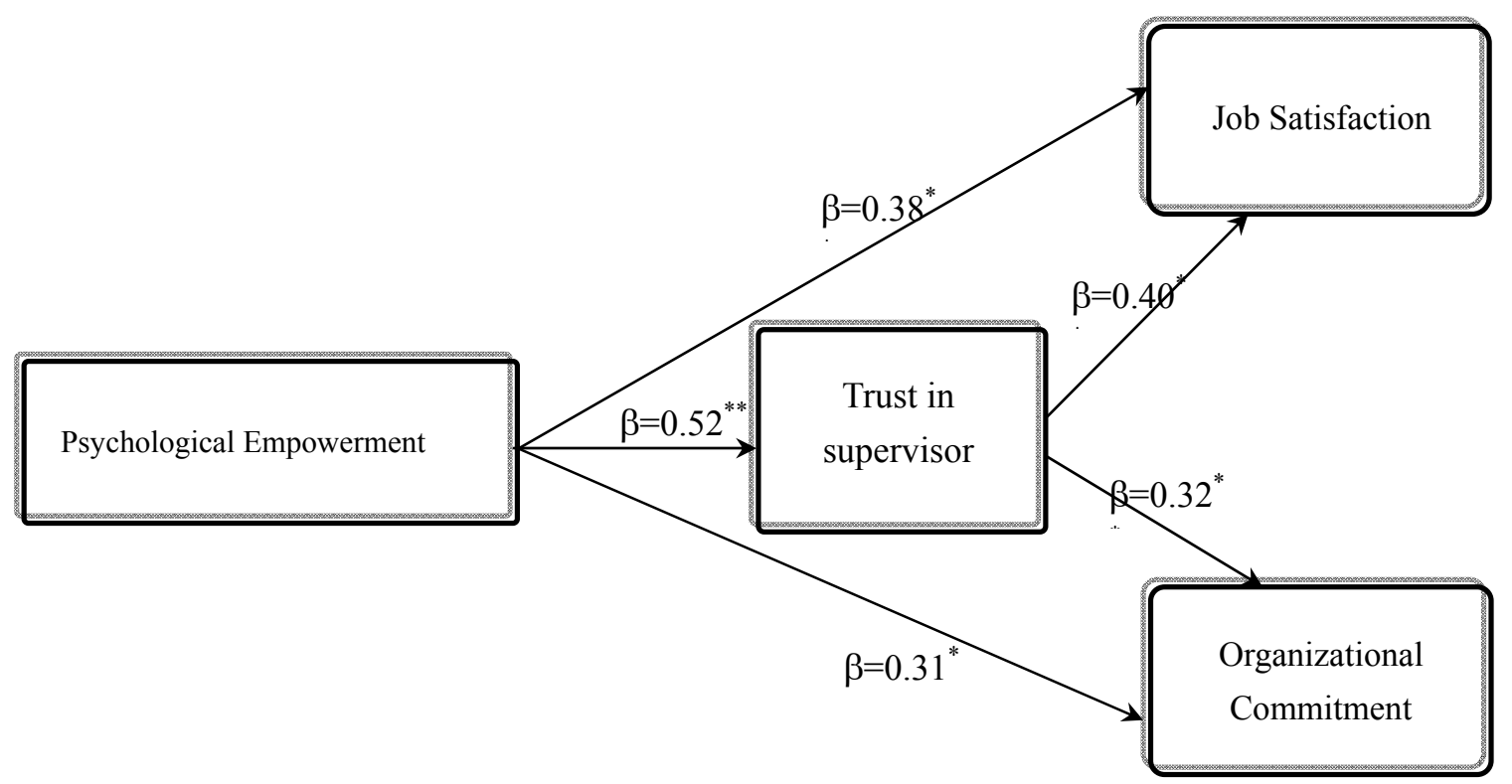

Figure 2. Framework

H3.b. "Subordinate trust in organization-as a mediator variable-significantly affects the relationship between psychological empowerment on one hand and job satisfaction and organizational commitment on the other hand."

The data illustrated in Table 13 will be used to discuss the hypothesis H03.b.

Table 13. Regression analysis for testing H03.b

\begin{tabular}{llccccc}
\hline Outcome Variable & Predictor(s) & $\mathbf{R}$ & $\mathbf{R}^{\mathbf{2}}$ & $\mathbf{F}$ & $\boldsymbol{\beta}$ 's & $\mathbf{p}$-value \\
\hline Internal & Psychological Empowerment & 0.40 & 0.16 & $12.8^{* *}$ & 0.40 & 0.001 \\
Organizational Trust & Internal Organizational Trust & \multirow{2}{*}{0.67} & 0.45 & $27.3^{* *}$ & 0.35 & 0.001 \\
& Psychological Empowerment & & & & 0.45 & 0.000 \\
Job Satisfaction & Internal Organizational Trust & \multirow{2}{*}{0.65} & 0.42 & $24.4^{* *}$ & 0.48 & 0.000 \\
& Psychological Empowerment & & & 0.28 & 0.007 \\
Organizational & Commitment & &
\end{tabular}

** Significant at 0.001 .

It is clear from the table above that the Psychological Empowerment is significantly and positively related to Job 
Satisfaction through the mediator variable (Internal Organizational Trust) since $(\beta=0.35, p-$ value $<0.01)$. In addition, Psychological Empowerment is significantly and positively related to Organizational Commitment through the mediator variable (Internal Organizational Trust) since $(\beta=0.48, p-$ value $<0.01)$. From this discussion, H03.b is highly supported by the data.

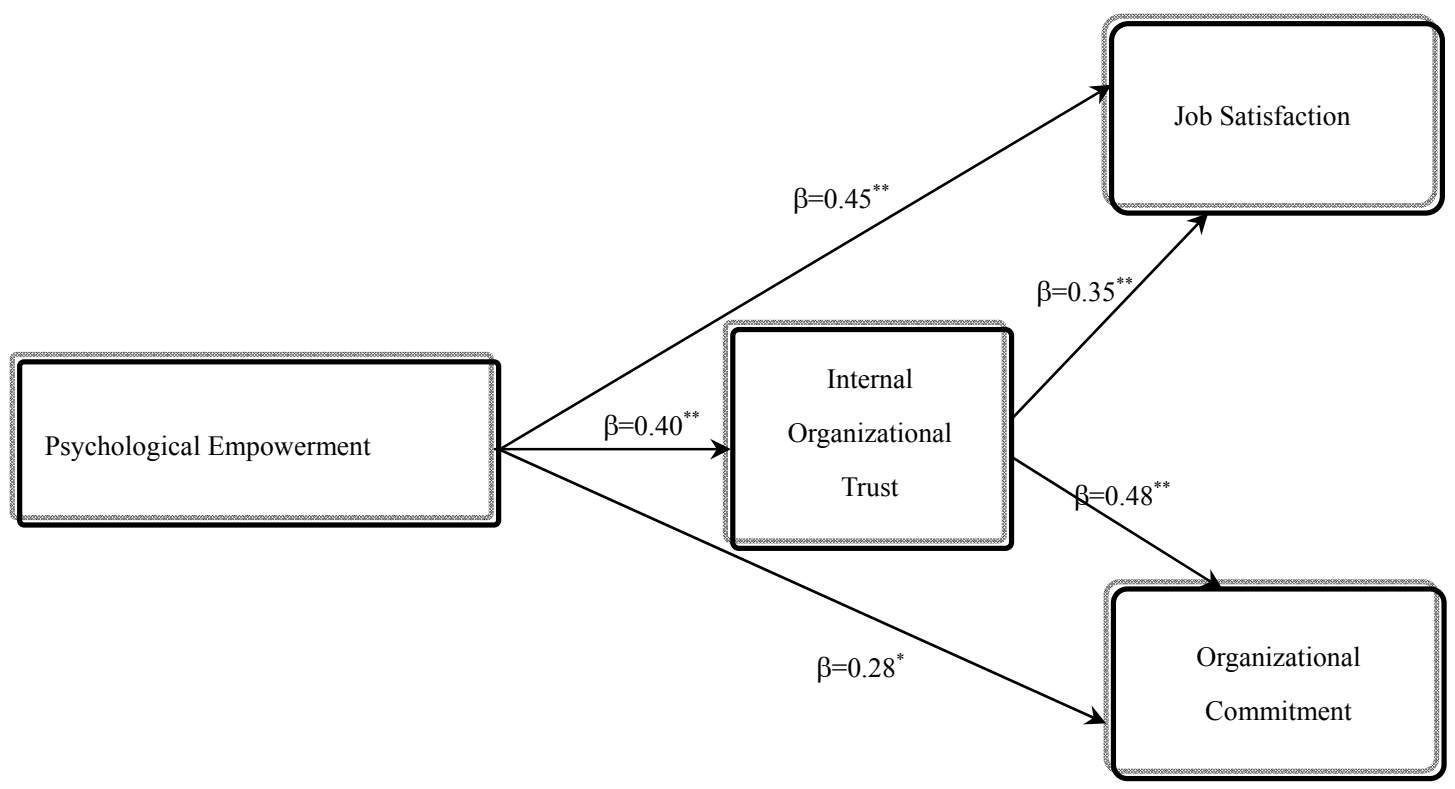

Figure 3. Framework

To measure the impact of the mediator variable, the method of Fairchild et al. (2009) has been followed. They derived a measure of effect size for the indirect effect in simple mediation analysis which is an attempt to quantify the proportion of the variance in $\mathrm{Y}$ (Dependent Variable) attributable to the indirect effect of $\mathrm{X}$ (Independent Variable) on $\mathrm{Y}$ through $\mathrm{M}$ (Mediator Variable). Their measure, which they label $R_{\text {med }}^{2}$, is calculated as

$$
R_{\text {med }}^{2}=r_{M Y}^{2}-\left(R_{Y . M X}^{2}-r_{X Y}^{2}\right)
$$

where $r_{M Y}^{2}$ and $r_{X Y}^{2}$ are the squared correlation between $\mathrm{M}$ and $\mathrm{Y}$ and $\mathrm{X}$ and $\mathrm{Y}$, respectively, and $R_{Y . M X}^{2}$ is the squared multiple correlation estimating $\mathrm{Y}$ from both $\mathrm{X}$ and $\mathrm{M}$.

Table 14 illustrates the required measurements needed to evaluate the mediation effect for Model 1.

Table 14. Values of R2 in model 1

\begin{tabular}{llc}
\hline Outcome Variable & Predictor(s) & $\mathbf{R}^{\mathbf{2}}$ \\
\hline Model 1: & & 0.345 \\
Job Satisfaction $\left(\mathrm{Y}_{1}\right)$ & Psychological Empowerment (X) & 0.224 \\
Organizational Commitment $\left(\mathrm{Y}_{2}\right)$ & & 0.402 \\
Job Satisfaction $\left(\mathrm{Y}_{1}\right)$ & Organizational Trust (M) & 0.335 \\
Organizational Commitment $\left(\mathrm{Y}_{2}\right)$ & Organizational Trust (M) & 0.490 \\
Job Satisfaction $\left(\mathrm{Y}_{1}\right)$ & Psychological Empowerment (X) & 0.375 \\
Organizational Commitment $\left(\mathrm{Y}_{2}\right)$ & Organizational Trust (M) \\
\hline
\end{tabular}

In the first model (where the dependent variable is Job Satisfaction $\left(\mathrm{Y}_{1}\right)$ ), simple mediation analysis, $r_{M Y_{1}}^{2}=$ $0.402, r_{X Y_{1}}^{2}=0.345$, and $R_{Y_{1} . M X}^{2}=0.490$, and so

$$
R_{\text {med }}^{2}=r_{M Y_{1}}^{2}-\left(R_{Y_{1}, M X}^{2}-r_{X Y_{1}}^{2}\right)=0.402-(0.490-0.345)=0.257
$$

In contrast (where the dependent variable is Organizational Commitment $\left(\mathrm{Y}_{2}\right)$ ), simple mediation analysis, $R_{m e d}^{2}=r_{M Y_{2}}^{2}-\left(R_{Y_{2} \cdot M X}^{2}-r_{X Y_{2}}^{2}\right)$, and so: 


$$
R_{\text {med }}^{2}=0.335-(0.375-0.224)=0.184
$$

As we have seen, and if we consider that approximately $49 \%$ and $38 \%$ of the total variance in Job Satisfaction and Organizational Commitment are explained $\left(\mathrm{R}^{2}=0.490,0.375\right.$ respectively), we can say that about $52 \%$ and $49 \%(0.257 / 0.490$ and $0.184 / 0.375$ respectively) of the explained variance in Job Satisfaction and Organizational Commitment was due to the mediated effect. Similarly, about $53 \%$ and $52 \%$ of the explained variance in Job Satisfaction and Organizational Commitment respectively was due to the mediated effect measured by Trust in Supervisors, while about $39 \%, 37 \%$ of the explained variance in these two variables respectively was due to the mediated effect measured by Internal Organizational Trust.

\section{Discussion}

In general, the results provide support for almost all the hypotheses of the study. The results indicate that the chosen independent, dependent, and mediate variables have significant relationships. The discussion in respect of each of the minor hypothesis is given below.

For the first hypothesis, the study concludes that Psychological Empowerment is a significant predictor of employee's Job Satisfaction. The results show that Psychological Empowerment explains about 33.5\% of the variation in the Job Satisfaction. This can go with Seibert et al. (2004) and Avey et al. (2008) who believe that job satisfaction is one of the most important results of psychological empowerment. It also good with what other researchers' findings about the relationship between Psychological Empowerment and Job Satisfaction (Laschinger et al., 2000; Liden et al., 2000; Ugboro \& Obeng, 2000; Bordin et al., 2007; Gazzoli et al., 2010). Regarding the relationships between dimensions of Psychological Empowerment and Job Satisfaction, the results show that two dimensions of Psychological Empowerment, Meaning and Impact, are significant and positively related to Job Satisfaction. The other two dimensions of Psychological Empowerment (Competence, and Self Determination) were statistically not contributed to Psychological Empowerment, since their effects are not significant. Comparing with the previous research, it can be concluded that meaning dimension can go along with these research findings which emphasize the importance of this dimension to Job Satisfaction. (Hackman \& Oldham, 1980; Spreitzer et al., 1997; Thomas \& Tymon, 1994; Liden et al., 2000; Carless, 2004). Regarding the impact dimension, there was some different evidence about its relationship with Psychological Empowerment, as shown previously in the literature review. The results support other research findings about the existence of a positive relationship between the impact and job satisfaction (Thomas \& Tymon, 1994). Liden et al. (2000) claimed that when employees have a feeling that the work they do can affect the outcomes within their organization, they will feel actively involved and therefore build a sense of job satisfaction (Abdullah et al., 2015). Regarding Self-Determination, the researchers suggested that it is a psychological need, and satisfying this need will lead to job satisfaction (Conger \& Kanungo, 1988; Greenberger et al., 1989; Parker, 1993), but the results of this study did not confirm this conclusion. Finally, regarding Competence, there is no agreement in the studies on the existence of a relationship between Competence dimension and satisfaction and the results show no relationship with psychological empowerment.

As for the influence of psychological empowerment on organizational commitment (second hypothesis), the study found that there is a positive relation between psychological empowerment, affective commitment, and normative commitment; while there is no relation between psychological empowerment and continuance commitment, which is consistent with the findings of Dehkordi et al. (2011). In addition, these results can be interpreted in accordance with the argument of Liden et al. (2000) who assert that empowerment may cause a sense of organizational commitment through a process of exchange. It was also supported by the findings of the Joo and Shim (2010), who found that psychological empowerment, is a predictor of organizational commitment. This is a logical consequence because when employees see that their work is meaningful to them, that their jobs help them acquire the skills and competencies required for the job, and they feel they can affect the results of their work, they would be more attached to their organizations (Abdullah et al. 2015). When the study investigates the relationships between dimensions of Psychological Empowerment and dimensions of organizational Commitment, it was found that only one dimension of Psychological Empowerment, Meaning, is significant and positively related to Affective Commitment, while the other three dimensions of Psychological Empowerment (Competence, Self Determination, and Impact) are statistically not contributed to Affective Commitment. Also, it was found that the two dimensions of Psychological Empowerment, Meaning and Competence, are significant and positively related to Normative Commitment; while the others two dimensions of Psychological Empowerment (Self Determination, and Impact) are statistically not contributed to Normative Commitment. For Continuance Commitment, no dimensions of Psychological Empowerment are statistically contributed to Continuance Commitment. 
The results of the study showed that the psychological empowerment as a whole has a positive impact on organizational commitment. However, in this study only two of the dimensions namely the meaning and competence predicted two dimensions of organizational commitment, namely the Affective Commitment and Normative Commitment. Compared with previous studies, these results are consistent only with the importance of meaning dimension as predictor of Affective Commitment and Normative Commitment. Cultural differences may be a possible reason why psychological empowerment does not significantly affect the organizational commitment and should be investigated in further research.

Regarding the role of Organizational Trust-as a mediator variable - between Psychological Empowerment on one hand and Job Satisfaction and Organizational Commitment on the other hand (third hypothesis), where in this study, Organizational Trust was looking at it in this study as consisting of two related, but separate, namely, internal organizational trust and trust in immediate supervisors (Nyhan \& Marlowe, 1997). The study found that Psychological Empowerment is significantly and positively related to Job Satisfaction and Organizational Commitment through the mediator variable. In this regard, the study has found that trust as a mediator variable has enhanced the influence of psychological empowerment, where the variance in Job Satisfaction and Organizational Commitment which is explained by psychological empowerment have risen from $33.5 \%$ to $52 \%$ for Job Satisfaction and $21.3 \%$ to $49 \%$ for Organizational Commitment. A significant contribution of this study is to provide empirical evidence of the importance of trust in the promotion of psychological empowerment. The results of the study clarify that trust in supervisor is more important than Internal Organizational Trust. Therefore, supervisors who display trust will create high levels of Job Satisfaction and Organizational Commitment with their subordinates. This result is agrees with Chan et al. (2008) that the effectiveness of the use of psychological empowerment to influence the behavior of workers depends on the level of subordinates trust in their supervisors Also, its agreement with the previous researches (Jian et al., 2011; Gomez \& Rosen, 2001), have stated that there is a correlation between trust in the supervisors and the empowerment of workers. In addition, the availability of trust leads to improve the relationship and thus developing supervisor's attitudes towards the empowerment of their subordinates.

\section{Limitations and Future Research}

There are a number of limitations that should be noted here. First, this study examined psychological empowerment affecting organizational commitment, job satisfaction, and organizational trust in the context of free trade zone alone. As a result, there may be differences in the findings between this sample and other sample from government and private organizations, therefore, generalizing the findings to other organizations must be cautiously. Research in the future seeking to determine a relationship between psychological empowerment, job satisfaction, organizational commitment, and trust may want to expand of the present study to include a larger sample size, both public and private organizations.

Also, this paper has not addressed the influence of demographic variables like age and years of experience. Future research should aim to explore the link between psychological empowerment and demographics variables which would help in revealing the change or shift in the employee perception of psychological empowerment. Lastly, this research concentrates on the effects of psychological empowerment on two job outcome variables, those are, job satisfaction and organizational commitment. Future research should examine other workplace outcome variables such as performance, innovation, team work, and creativity. Antecedents of psychological empowerment should also be investigated which will allow researchers to gain a better understanding of psychological empowerment in the workplace.

\section{References}

Abdullah, A. G. K. B., Almadhoun, T. Z., \& Ling, Y. L. (2015). Psychological empowerment, job satisfaction and commitment among Malaysian secondary school teachers. Asian Journal of Educational Research, 3(3), 34-42.

Allen, N. J., \& Grisaffe, D. B. (2001). Employee commitment to the organization and customer reactions: Mapping the linkages. Human Resource Management Review, 11, 209-236. http://dx.doi.org/10.1016/S1053-4822(00)00049-8

Allen, N. J., \& Meyer, J. P. (1990). The measurement and antecedents of affective, continuance and normative commitment to the organization. Journal of Occupational Psychology, 63(1), 1-18. http://dx.doi.org/10.1111/j.2044-8325.1990.tb00506.x

Andrews, G. M. (1994). Mistrust, the hidden obstacle to empowerment. HR Magazine, 39, 66-70.

Appelbaum, S. T., Hebert, D., \& Leroux, S. (1999). Empowerment: Power culture and leadership: A strategy or 
fad for the millennium? Journal of Workplace Learning: Employee Counselling Today, 11(7), 1-22. http://dx.doi.org/10.1108/13665629910291929

Avey, J. B., Hughes, L. W., Norman, S. M., \& Luthans, K. W. (2008). Using positivity, transformational leadership and empowerment to combat employee negativity. Leadership \& Organization Development Journal, 29(2), 110-126. http://dx.doi.org/10.1108/01437730810852470

Bateman, T., \& Strasser, S. (1984). A longitudinal analysis of the antecedents of organizational commitment. Academy of Management Journal, 27(1), 95-112. http://dx.doi.org/10.2307/255959

Bhatnagar, J. (2005). The power of psychological empowerment as an antecedent to organizational commitment in Indian managers. Human Resource Development International, 8(4), 419-433. http://dx.doi.org/10.1080/13678860500356101

Bordin, C., Bartram, T., \& Casimir, G. (2007). The antecedents and consequences of psychological empowerment among Singaporean IT employees. Management Research News, 30(1), 34-46. http://dx.doi.org/10.1108/01409170710724287

Bowen, D. E., \& Lawler, E. E. (1992). The Empowerment of Service Workers: What, Why, How, and When. Sloan Management Review, 33(3), 31-39.

Brashear, T. G., Boles, J. S., Bellenger, D. N., \& Brooks, C. M. (2003). An Empirical Test of Trust-building Processes and Outcomes in Sales Manager -Salesperson Relationships. Academy of Marketing Science Journal, 31(2), 189-200. http://dx.doi.org/10.1177/0092070302250902

Brower, H. H., Lester, S. W., Korsgaard, M. A., \& Dinen, B. R. (2009). A Closer Look at Trust between Managers and Subordinates: Understanding the Effects of Both Trusting and Being Trusted on Subordinate Outcomes. Journal of Management, 35(2), 327-347. http://dx.doi.org/10.1177/0149206307312511

Carless, S. A. (2004). Does psychological empowerment mediate the relationship between psychological climate and job satisfaction? Journal of Business and Psychology, 18(4), 405-425. http://dx.doi.org/10.1023/B:JOBU.0000028444.77080.c5

Chan, Y. H., Taylor, R. R., \& Markham, S. (2008). The Role of Subordinates' Trust in a Social Exchange-driven Psychological Empowerment Process. Journal of Managerial Issues, 20(4), 444-467.

Chen, H. F., \& Chen, Y. C. (2008). The impact of work redesign and psychological empowerment on organizational commitment in a changing environment: An example from Taiwan's state-owned enterprises. Public Personnel Management, 37(3), 279-302. http://dx.doi.org/10.1177/009102600803700302

Colquitt, J. A., Scott, B. A., \& Le Pine, J. A. (2007). Trust, Trustworthiness, and Trust Propensity: A Meta-analytic Test of Their Unique Relationships with Risk Taking and Job Performance. Journal of Applied Psychology, 92, 902-927. http://dx.doi.org/10.1037/0021-9010.92.4.909

Colyle-Shapiro, J., \& Kessler, J. (2000). Consequences of psychological contract for the employment relationship: a large scale survey. Journal of Management Studies, 37(7), 903-930. http://dx.doi.org/10.1111/1467-6486.00210

Conger, J., \& Kanungo, R. (1988). The empowerment process: integrating theory and practice. Academy of Management Review, 13(3), 471-482. http://dx.doi.org/10.1037/0033-2909.131.2.241

Cook, J., \& Wall, T. (1980). New Work Attitude Measure of Trust, Organizational Commitment and Personal Need Non-fulfilment. Journal of Occupational Psychology, 53(1), 39-52. http://dx.doi.org/10.1111/j.2044-8325.1980.tb00005.x

Cooper-Hakim, A., \& Viswesvaran, C. (2005). The construct of work commitment: Testing an integrative framework. Psychological Bulletin, 131(2), 241-259. http://dx.doi.org/10.1177/0149206305279602

Covey, S. R. (1998). Servant leadership from the inside out. In L. Spears (Ed.), Insights on Leadership (pp. 11-18). New York: Wiley.

Cropanzano, R., \& Mitchell, M. S. (2005). Social Exchange Theory: An Interdisciplinary Review. Journal of Management, 31(6), 874-900.

De Cotiis, T. A., \& Summers, T. P. (1987). A path-analysis of a model of the antecedents and consequences of $\begin{array}{llll}\text { organizational } \quad \text { commitment. Human } & \text { Relations, }\end{array}$ http://dx.doi.org/10.1177/001872678704000704

Dehkordi, L. F., Kamrani, M. N., Ardestani, H., M., \& Abdolmanafi, S. (2011). Correlation between 
Psychological Empowerment with Job Satisfaction and Organizational Commitment. Interdisciplinary Journal of Contemporary Research in Business, 3(7), 808-822.

Dirks, K. T., \& Ferrin, D. L. (2002). Trust in Leadership: Meta-analytic Finding. http://dx.doi.org/10.2307/255661

Donovan, M. (1994). The empowerment plan. Journal for Quality and Participation, 17(4), 12-14.

Driscoll, J. W. (1978). Trust and Participation in Organizational Decision Making as Predictors of Satisfaction. Academy of Management Journal, 21(1), 44-56.

Eisenberger, R., Fasolo, P. M., \& Davis-LaMastro, V. (1990). Perceived organizational support and employee diligence, commitment and innovation. Journal of Applied Psychology, 75, 51-59. http://dx.doi.org/10.1037/0021-9010.75.1.51

Ertürk, A. (2010). Exploring predictors of organizational identification: Moderating role of trust on the associations between empowerment, organizational support and identification. European Journal of Work and Organizational Psychology, 19(4), 409-441. http://dx.doi.org/10.1080/13594320902834149

Ertürk, A. (2012). Linking Psychological Empowerment to Innovation Capability: Investigating the Moderating Effect of Supervisory Trust. International Journal of Business and Social Science, 3(14), 153-165.

Fairchild, A. J., \& Mackinnon, D. P., Toborga, M. P., \& Taylor, A. B. (2009). R-Squared effect-size measures for mediation analysis. Behavior Research Methods, 41(2), 486-498. http://dx.doi.org/10.3758/BRM.41.2.486

Fernandes, C., \& Awamleh, R. (2006). Impact of Organizational Justice in an Expatriate Work Environment. Management Research News, 29(11), 701-712. http://dx.doi.org/10.1108/01409170610716016

Fulford, M. D., \& Enz, C. A. (1995). The impact of empowerment on service employees. Journal of Managerial Issues, 7(2), 161-175.

Gazzoli, G., Hancer, M., \& Park, Y. (2010). The role and effect of job satisfaction and empowerment on customers' perception of service quality: A study in the restaurant industry. Journal of Hospitality \& Tourism Research, 34(1), 56-77. http://dx.doi.org/10.1177/1096348009344235

George, D., \& Mallery, P. (2003). SPSS for Windows step by step: A simple guide and reference (4th ed.). Boston: Allyn \& Bacon.

Gilbert, J. A., \& Tang, T. L. P. (1998). An Examination of Organizational Trust Antecedents. Public Personnel Management, 27(3), 321-338. http://dx.doi.org/10.1177/009102609802700303

Gomez, C., \& Rosen, B. (2001). The Leader-Member Exchange a Link between Managerial Trust and Employee

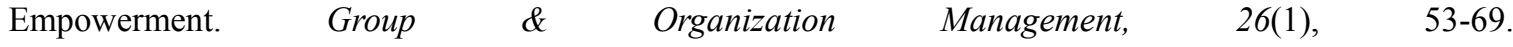
http://dx.doi.org/10.1177/1059601101261004

Greasley, K., Bryman, A., Dainty, A., Price, A., Naismith, N., \& Soetanto, R. (2008). Understanding empowerment from an employee perspective. Team Performance Management, 14(1/2), 39-55. http://dx.doi.org/10.1108/13527590810860195

Greasley, K., Bryman, A., Dainty, A., Price, A., Soetanto, R., \& King, N. (2005). Employee perceptions of empowerment. Employee Relations, 27(4), 354-368. http://dx.doi.org/10.1108/01425450510605697

Greenberger, D. B., Strausser, S., Cummings, L. L., \& Dunham, R. (1989). The impact of personal control on performance and satisfaction. Organizational Behavior and Human Decision Processes, 43, 29-51. http://dx.doi.org/10.1016/0749-5978(89)90056-3

Hackman, J. R., \& Oldham, G. R. (1980). Work redesign. MA: Addison-Wesley.

Hall, M. (2008). The effect of comprehensive performance measurement systems on role clarity, psychological empowerment and managerial performance. Accounting, Organizations and Society, 33(2-3), 141-163. http://dx.doi.org/10.1016/j.aos.2007.02.004

Herrbach, O. (2006). A matter of feeling: The affective tone of organizational commitment and identification. Journal of Organizational Behavior, 27(5), 629-643. http://dx.doi.org/10.1002/job.362

Hislop, D. (2003). Linking human resource management and knowledge management via commitment: A review and research agenda. Employees Relations, 25(2), 182-202. http://dx.doi.org/10.1108/01425450310456479

Holdsworth, L., \& Cartwright, S. (2003). Empowerment, stress and satisfaction: An exploratory study of a call centre. Leadership \& Organization Development Journal, 24(3), 131-140. 
http://dx.doi.org/10.1108/01437730310469552

Hong, L. U., Alison, E., While, K., \& Barribal, L. (2007). Job Satisfaction and its Related Factors: A questionnaire survey of hospital nurses in Mainland China. International Journal of Nursing Studies, 44(4), 574-588. http://dx.doi.org/10.1016/j.ijnurstu.2006.07.007

Jha, S. (2011). Influence of Psychological Empowerment on Affective and Normative and Continuance commitment: A study in Indian IT industry. Journal of Indian Business Research, 3(4), $263-282$. http://dx.doi.org/10.1108/17554191111180582

Jiang, C. X., Chua, R. Y. J., Kotabe, M., \& Murray, J. Y. (2011). Effects of cultural ethnicity, firm size, and firm age on senior executives' trust in their overseas business partners: Evidence from China. Journal of International Business, 42(9), 1150-1173. http://dx.doi.org/10.1057/jibs.2011.35

Joo, B. K., \& Shim, J. H. (2010). Psychological empowerment and organizational commitment: The moderating effect of organizational learning culture. Human Resource Development International, 13(4), 425-441. http://dx.doi.org/10.1080/13678868.2010.501963

Kanter, R. M. (1989). The new managerial work. Harvard Business Review, 66, 85-92.

Kim, S., O’Neill, J. W., \& Jeong, S. (2004). The Relationship among Leader-Member Exchange, Perceived Organizational Support, and Trust in Hotel Organizations. Journal of Human Resources in Hospitality \& Tourism, 3(1), 59-70. http://dx.doi.org/10.1300/J171v03n01_06

Koberg, C. S., Boss, R. W., Senjem, J. C., \& Goodman, E. A. (1999). Antecedents and outcomes of empowerment: Empirical evidence from the health care industry. Group and Organization Management, 24(1), 71-91. http://dx.doi.org/10.1177/1059601199241005

Kraimer, M. L., Seibert, S. E., \& Liden, R. C. (1999). Psychological empowerment as a multidimensional construct: A test of construct validity. Educational and Psychological Measurement, 59(1), $127-142$. http://dx.doi.org/10.1177/0013164499591009

Laschinger, H. K. S., \& Finegan, J. (2005). Using Empowerment to Build Trust and Respect in the Workplace: A Strategy for Addressing the Nursing Shortage. Nursing Economics, 23(1), 6-13.

Laschinger, H. K. S., Finegan, J., Shamian, J., \& Wilk, P. (2004). A longitudinal analysis of the impact of workplace empowerment on work satisfaction. Journal of Organizational Behavior, 25(4), 527-545. http://dx.doi.org/10.1002/job.256

Lewicki, R. J., Tomlinson, E., \& Gillespie, N. (2006). Models of interpersonal trust development: Theoretical approaches, empirical evidence, and future directions. Journal of Management, 32(6), 991-1022. http://dx.doi.org/10.1177/0149206306294405

Liden, R. C., Wayne, S. J., \& Sparrowe, R. T. (2000). An examination of the mediating role of psychological empowerment on the relations between the job, interpersonal relationships, and work outcomes. Journal of Applied Psychology, 85(3), 407. http://dx.doi.org/10.1037/0021-9010.85.3.407

Liu, A. M. M., Fellows, R., \& Chiu, W. M. (2006). Work empowerment as an antecedent to organisational commitment in the Hong Kong quantity surveying profession. Surveying and Built Environment, 17(2), 63-72.

Mayer, R. C., \& Gavin, M. B. (2005). Trust in Management and Performance: Who Minds the Shop while the Employees Watch the Boss? Academy of Management Journal, 48(5), 874-888. http://dx.doi.org/10.5465/AMJ.2005.18803928

Menon, S. T. (2001). Employee empowerment: An integrative psychological approach. Applied Psychology: An International Review, 50(1), 153-180. http://dx.doi.org/10.1111/1464-0597.00052

Meyer, J. P., \& Allen, N. J. (1991). A three-component conceptualization of organizational commitment. Human Resource Management Review, 1(1), 61-89. http://dx.doi.org/10.1016/1053-4822(91)90011-Z

Meyer, J. P., \& Allen, N. J. (1997). Commitment in the Workplace: Theory Research and Application. Sage, London.

Meyer, J. P., \& Herscovitch, L. (2001). Commitment in the workplace: Toward a general model. Human Resource Management Review, 11(3), 299-326. http://dx.doi.org/10.1016/S1053-4822(00)00053-X

Mishra, J., \& Morrissey, M. A. (1990). Trust in employee/employer relationships: A survey of west Michigan managers. Public Personnel Management, 19(4), 443-485. http://dx.doi.org/10.1177/009102609001900408 
Moye, M. J., \& Henkin, A. B. (2005). Teacher-Principal Relationships: Exploring Linkages between Empowerment and Interpersonal Trust. Journal of Educational Administration, 43(3), 260-277. http://dx.doi.org/10.1108/09578230510594796

Nyhan, R. C., \& Marlowe, H. A. (1997). Development and Psychometric Properties of Organisational Trust Inventory. Evaluation Review, 21(5), 614-635. http://dx.doi.org/10.1177/0193841X9702100505

Parker, L. (1993). When to fix it and when to leave: Relationships among perceived control, self-efficacy, dissent, and exit. Journal of Applied Psychology, 78(6), 949-959. http://dx.doi.org/10.1037/0021-9010.78.6.949

Parnell, J. A., \& Crandall, W. (2003). Propensity for Participative Decision-making, Job Satisfaction, Organisational Commitment and Intention to Leave among Egyptian Managers. Multinational Business Revie, 11(1), 45-65. http://dx.doi.org/10.1108/1525383X200300003

Pierce, J., \& Gardner, D. (2004). Self-esteem within the Work and Organizational Context: A Review of the Organization-based Self-esteem Literature. Journal of Management, 30(5), 591-622. http://dx.doi.org/10.1016/j.jm.2003.10.001

Powell, D. M., \& Meyer, J. P. (2004). Side-Bet Theory and the Three-Component Model of Organizational $\begin{array}{lllll}\text { Commitment. Journal of } & \text { Vocational }\end{array}$ http://dx.doi.org/10.1016/S0001-8791(03)00050-2

Preacher, K. J., \& Hayes, A. F. (2008). Asymptotic and resampling strategies for assessing and comparing indirect effects in multiple mediator models. Behavior Research Methods, 40(3), 879-891. http://dx.doi.org/10.3758/BRM.40.3.879

Robbins, S. P. (2002). Organizational Behavior (10th ed.). Prentice Hall.

Robbinson, S., Krant, M., \& Rossouw, D. (1994). Changing obligations and the psychological contract: A longitudinal study. Academy of Management Journal, 37(1), 137-152. http://dx.doi.org/10.2307/256773

Rousseau, D., Sitkin, S., Burt, R., \& Camerer, C. (1998). Not so different after all: A cross-discipline view of trust. Academy of Management Review, 23(3), 393-404. http://dx.doi.org/10.5465/AMR.1998.926617

Seibert, S. E., Silver, S. R., \& Randolph, W. A. (2004). Taking empowerment to the next level: A multiple-level model of empowerment, performance, and satisfaction. Academy of Management Journal, 47(3), 332-349. http://dx.doi.org/10.2307/20159585

Siegall, M., \& Gardner, S. (2000). Contextual factors of psychological empowerment. Personnel Review, 29(6), 703. http://dx.doi.org/10.1108/00483480010296474

Spreitzer, G. M. (1995). Psychological empowerment in the workplace: Dimensions, measurement, and validation. Academy of Management Journal, 38(5), 1442-1465. http://dx.doi.org/10.2307/256865

Spreitzer, G. M. (1996). Social structural characteristics of psychological empowerment. Academy of Management Journal, 39(2), 483-504. http://dx.doi.org/10.2307/256789

Spreitzer, G. M., Kizilos, M. A., \& Nason, S. W. (1997). A dimensional analysis of the relationship between psychological empowerment and effectiveness, satisfaction, and strain. Journal of Management, 23(5), 679-704. http://dx.doi.org/10.1177/014920639702300504

Suzik, H. A. (1998). Transmission plant is winner with empowerment. Quality, 37(4), 90-91.

Tan, H. H., \& Tan, C. (2000). Toward the Differentiation of Trust in Supervisor and Trust in Organization. Genetic, Social, and General Psychology Monographs, 126(2), 241-260.

Thomas, K. W., \& Velthouse, B. A. (1990). Cognitive elements of empowerment: An "interpretive" model of intrinsic task motivation. Academy of Management Review, 15(4), 666-681.

Thomas, K., \& Tymon, W. (1994). Does empowerment always work: Understanding the role of intrinsic motivation and personal interaction. Journal of Management Systems, 6(3), 39-54.

Ugboro, I. O., \& Obeng, K. (2000). Top Management Leadership, Employee Empowerment, Job satisfaction, and Customer Satisfaction in TQM Organizations: an empirical study. Journal of Quality Management, 5(2), 247-272. http://dx.doi.org/10.1016/S1084-8568(01)00023-2

Wang, G., \& Lee, P. (2009). Psychological Empowerment and Job Satisfaction: An Analysis of Interactive Effects. Group \& Organization Management, 34(3), 271-296. http://dx.doi.org/10.1177/1059601108330089

Whitener, E. M., Brodt, S. E., Korsgaard, M. A., \& Werner, J. M. (1998). Managers as Initiators of Trust: An 
Exchange Relationship Framework for Understanding Managerial Trustworthy Behavior. Academy of Management Review, 23(3), 513-530.

\section{Copyrights}

Copyright for this article is retained by the author(s), with first publication rights granted to the journal.

This is an open-access article distributed under the terms and conditions of the Creative Commons Attribution license (http://creativecommons.org/licenses/by/4.0/). 